\title{
Effect of Growth Velocity and Zn Content on Microhardness in Directionally Solidified Al- Zn Alloys
}

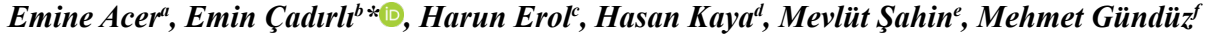

${ }^{a}$ Department of Physics, Erciyes University, Institute of Science, 38039, Kayseri, Turkey

${ }^{b}$ Department of Physics, Faculty of Arts and Sciences, Niğde Ömer Halisdemir University, 51100, Niğde, Turkey

${ }^{c}$ Department of Physics, Faculty of Science, Karatekin University, 18100, Çankirl, Turkey

${ }^{d}$ Department of Science Education, Faculty of Education, Erciyes University, 38039, Kayseri, Turkey

${ }^{e}$ Department of Electronics and Automation, Technical Vocational School of Sciences, Ömer Halisdemir University, 51100, Niğde, Turkey

${ }^{f}$ Department of Physics, Faculty of Science, Erciyes University, Kayseri, 38039, Turkey

Received: May 10, 2018; Revised: August 17, 2018; Accepted: August 21, 2018

In this study, $\mathrm{Al}-\mathrm{xZn}(\mathrm{x}=1,3,5,7,10$ and $20 \mathrm{wt}$. \%) alloys were prepared using metals of $99.99 \%$ high purity in the vacuum atmosphere. These alloys were directionally solidified upward with a constant temperature gradient, $\mathrm{G}(10.3 \mathrm{~K} / \mathrm{mm})$ and different growth velocities $(\mathrm{V})$ between 8.25 and $165 \mu \mathrm{m} / \mathrm{s}$ in the directional solidification apparatus. The experimental results have revealed that with the increase of the growth velocity of the melts from $8.25 \mu \mathrm{m} / \mathrm{s}$ to $165 \mu \mathrm{m} / \mathrm{s}$, the microstructures undergo a transition from cellular/cellular dendritic morphology to coarse dendritic form for each composition (Zn content, $\mathrm{C}_{\mathrm{o}}$ ). The measurements of microhardness (HV) of the specimens were performed by using a microhardness test device. The dependence of $\mathrm{HV}$ on $\mathrm{V}$ and $\mathrm{C}_{\mathrm{o}}$ was analyzed, and it has been found that with increasing the $\mathrm{V}$ and $\mathrm{C}_{\mathrm{o}}$ the $\mathrm{HV}$ increases. Relationships between $\mathrm{HV}-\mathrm{V}$ and $\mathrm{HV}-\mathrm{C}_{\mathrm{o}}$ were obtained by linear regression analysis, and the experimental results were compared with the results of previous similar works.

Keywords: Al-Zn alloys, microstructure, microhardness, growth velocity, directional solidification.

\section{Introduction}

Aluminum alloys are used in industry because of their corrosion resistance, low specific weight, heat and electrical conductivity. These properties make them valuable for use in various industrial applications, and researchers have been actively exploring new application for these alloys ${ }^{1-3}$. Aluminum-Zinc alloys, which constitute the basis of the 7000 series alloys, appear to be also very different from a fundamental point of view of solidification. Aluminum has a cubic structure with centered face and is slightly anisotropic whereas zinc has a hexagonal structure and is strongly anisotropic. This difference in anisotropy involves a variation of interfacial energy modifying morphologies and directions of dendritic growth. These alloys are saturated solid solutions which slowly break up and reach their state of equilibrium ${ }^{4,5}$. Al- $\mathrm{Zn}$ system has also positive heat of mixing ${ }^{6}$, and the solubility of $\mathrm{Zn}$ in $\mathrm{Al}$ at $20^{\circ} \mathrm{C}$ is less than 2 wt. $\%^{7}$ as seen in Fig. 1 . Many researchers ${ }^{8-11}$ studied this type of binary Al-Zn alloys and showed that the Al-Zn alloys provide distinctive resulting morphologies as a function of the applied cooling rate associated with $\mathrm{Zn}$ content examined. In lower $\mathrm{Zn}$ content $\left(\mathrm{C}_{0}=40 \mathrm{at} \% \mathrm{Zn}\right), \mathrm{Al}$ and $\mathrm{Zn}$ do not form intermetallic phases since the interaction between $\mathrm{Al}$ and $\mathrm{Zn}$ atoms is fairly week. In this study, $\beta$-phase was not present

*email: ecadirli@gmail.com. in the studied alloys since $\mathrm{Zn}$ content is low. However, some studies ${ }^{12-14}$ have reported monolithic $\beta$ and distinctive $\alpha+\beta$ phases in high $\mathrm{Zn}$ containing and heat treatment applied alloys.

Although the vast majority of casting and solidification processes in the industry are related to unsteady-state/transient directional solidification, it is seen that the great majority of studies examining the relationship between solidification microstructure parameters ( $\lambda 1$ : primary dendrite arm spacing, 22: secondary dendrite arm spacing) and processing parameters $\left(C_{o}, G, V, T(\right.$ cooling rate $\left.)\right)$ are related to controlled directional solidification (Bridgman-type) studies. If $\mathrm{V}$ is not too high, the cooling rate at a given time and region is given by;

$$
T=G V
$$

In unsteady-state/transient directional solidification and casting, the microstructure is no longer uniform along the specimen because the cooling rate, (V and $\mathrm{G})$, decreases as the distance from the cold zone increases ${ }^{15-18}$. In controlled directional solidification, generally the sample is homogeneous since $C_{o}, G, V, T$ are constant throughout the experiment. However, in the unsteady-state/transient directional solidification and casting, the initial solidification processing parameters are quite different from the lateral values as the solidification temperature and/or the solidliquid interface area are moved away from the cold zone. 


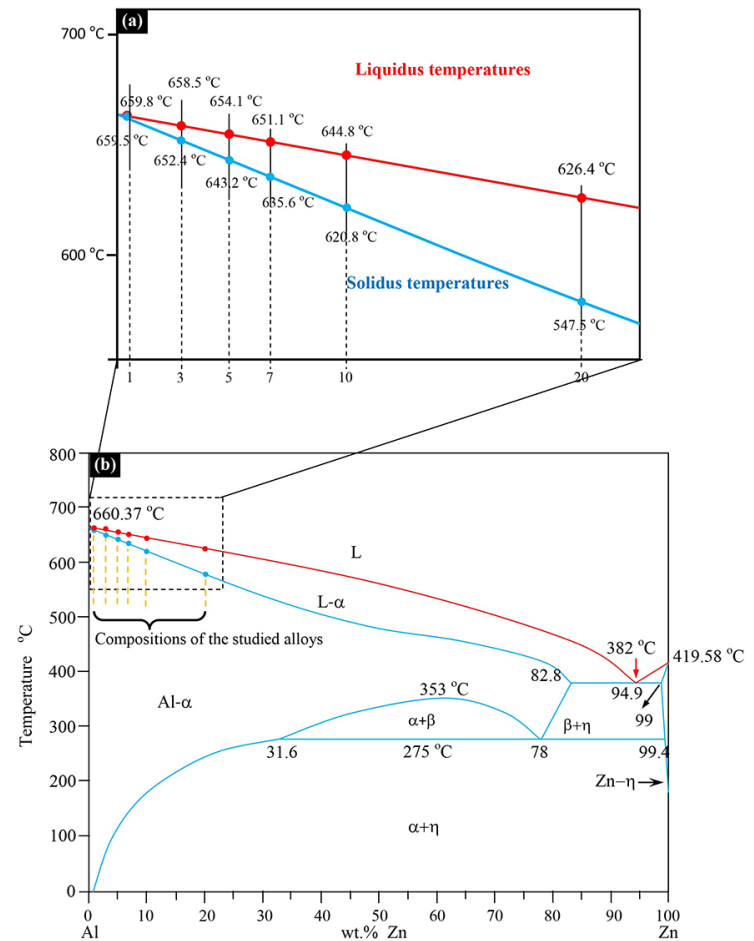

Figure 1. Phase diagram of Al-Zn system (a) partial view (studied compositions) (b) full view ${ }^{7}$.

Therefore, this affects the microstructure parameters, the homogeneity and thus the properties of the product ${ }^{18-20}$. For these reasons, in the unsteady-state/transient directional solidification experiments, the $C_{o}, G, V, T$ are measured ${ }^{21-23}$. However, in the case of controlled directional solidification, it is sufficient to measure these values once in the experiment since the $C_{o}, G, V, T$ values are constant during controlled directional solidification.

Dendritic morphologies are frequently observed during the solidification of alloys in which several directional solidification studies have been carried out to predict the growth conditions for development of the instability at the solid-liquid interface and characterize the microstructural features ${ }^{24-29}$. To minimize the convection in the alloys during solidification, it is necessary not only to have a hydrodynamic density gradient and $\mathrm{G}$, but also a horizontal density gradient, and $\mathrm{G}$ could be close to zero in the Bridgman method. The microstructural and mechanical properties of a material depend on not only the selection of alloying elements but also the production technique employed. The directional solidification technique by Bridgman-type equipment is one of the most important techniques for producing crystal growth that is widely utilized in engineering although Bridgman method is restricted to specimen diameters and is also expensive ${ }^{17}$. Aluminum and aluminum alloys are prone to having possible casting errors more than other alloys such as cracks and distortions due to volume shrinkage depressions. These errors can be minimized by using Bridgman's technique. When alloys are directionally solidified in Bridgman-type equipment, the solidification results in two or more phases aligned in growth direction. In directional solidification experiments, solidification processing variables such as the solidification front velocity, $\mathrm{V}$, the temperature gradient, $\mathrm{G}$, and composition of the material, $\mathrm{C}_{\mathrm{o}}$, can be independently controlled in order to study the dependence of the microstructure ${ }^{26-29}$. One of the most important quantities used to describe the solidified dendritic microstructure in directional solidification is the cellular and dendritic spacing. These microstructures are affected by the solidification processing variables. This microstructure of alloys affects their mechanical properties ${ }^{30-35}$. In a study by Lamrous et al. ${ }^{36}$ on Al-Zn alloys, the microhardness value increases with increasing $\mathrm{Zn}$ content. They have attributed this to the formation of precipitation that acts as an obstacle to the dislocation movement. According to them, two factors contributing to the improvement of hardness are solid solution hardening and refinement of grain size. It has widely been reported $^{37-41}$ that distribution phases and morphology of alloys have important roles on the resulting properties. These are intimately associated with the operational conditions applied indistinctively of the nature and characteristic of the examined material.

The aim of the present work was to experimentally investigate the effect of $\mathrm{V}$ and $\mathrm{C}_{\mathrm{o}}$ on the microstructure and $\mathrm{HV}$ in directionally solidified $\mathrm{Al}-\mathrm{xZn}(\mathrm{x}=1,3,5,7,10$ and 20 wt. \%) alloys and to compare the results with previous similar experimental results.

\section{Experimental Procedure}

\subsection{Specimen preparation and directional solidification process}

$\mathrm{Al}-\mathrm{xZn}(\mathrm{x}=1,3,5,7,10$ and $20 \mathrm{wt}$. \%) alloys were prepared under vacuum using $99.99 \%$ pure aluminum and $99.99 \%$ pure zinc metals. After allowing time for melt homogenization, each molten alloy was poured into a graphite crucible $(200 \pm 1$ mm length, $4.0 \pm 0.1 \mathrm{~mm}$ ID (inner diameter), $6.35 \pm 0.1 \mathrm{~mm}$ OD (outer diameter)) held in a specially constructed hotfilling furnace at approximately $100 \mathrm{~K}$ above the liquidus temperature of the alloy. When the pouring temperature is lower than the solidus temperature, the liquid alloy will freeze before filling the graphite crucible. On the other hand, if the pouring temperature is too high, turbulence can become a serious problem. When the pouring temperature is about $100 \mathrm{~K}$ higher than the liqudus temperature of the alloy the flow of the alloy is high enough and a casting without cavity can be made.

The molten alloy was directionally solidified from the bottom to the top to ensure that the graphite crucible was completely full. Three specimens were prepared from each alloy for reproducibility during sample preparation. Then, 
each specimen was positioned in a Bridgman-type growth apparatus. The details of the apparatus are given in Fig. 2. The Bridgman-type growth apparatus is widely used in industry and research mainly because it provides a means to directionally solidify materials in a controlled manner so that the resulting microstructure and hence material properties can be manipulated. Directional solidification of the specimens with a constant thermal gradient (10.3 $\mathrm{K} / \mathrm{mm}$ ) was performed at $1050 \mathrm{~K}$. After stabilizing the thermal conditions in the furnace under argon atmosphere, the specimens were grown by pulling them downwards by means of different speeded synchronous motors. After 8-10 $\mathrm{cm}$ steady state growth, the specimens were quenched by rapidly pulling them down into the water reservoir. The temperature of the specimen was also controlled to an accuracy of $\pm 0.1 \mathrm{~K}$ using a Eurotherm 2604 controller. The temperature gradient can be changed according to the type of crucible and the furnace temperature. The furnace was calibrated, and temperature gradients as high as $15 \mathrm{~K} / \mathrm{mm}$ were obtained near the solid-liquid interface. Solidification of the specimens in the graphite crucible was carried out with the different growth velocities $(\mathrm{V}=8.25-165 \mu \mathrm{m} / \mathrm{s})$ and constant temperature gradient $(\mathrm{G}=10.3 \mathrm{~K} / \mathrm{mm})$.

\subsection{Measurement of solidification processing parameters $(G, V)$ and metallographic process}

The temperature in the specimen was measured with K-type $500 \mu \mathrm{m}$ in diameter insulated three thermocouples which were fixed within the specimen with spacing of 10 $\mathrm{mm}$. All the thermocouple's ends were connected to the measurement unit consisting of data-logger and computer. The cooling rates were recorded with a data-logger via computer during the growth. When the solid/liquid interface was at the second thermocouple, the temperature difference between the first and second thermocouples $(\Delta T)$ was red from data-logger record. The time taken for the solid-liquid interface to pass through the thermocouples separated by known distances was read from the data-logger record. Thus, the value of growth velocity $(V=\Delta X / \Delta t)$ for each specimen was determined using the measured value of $\Delta \mathrm{t}$ and known value of $\Delta X$. The temperature gradient $(G=\Delta T / \Delta X)$ in the liquid phase for each specimen was also determined using the measured values of $\Delta \mathrm{T}$ and $\Delta \mathrm{X}$.

The quenched specimens were removed from the graphite crucible, and they were cropped off and discarded $3 \mathrm{~cm}$

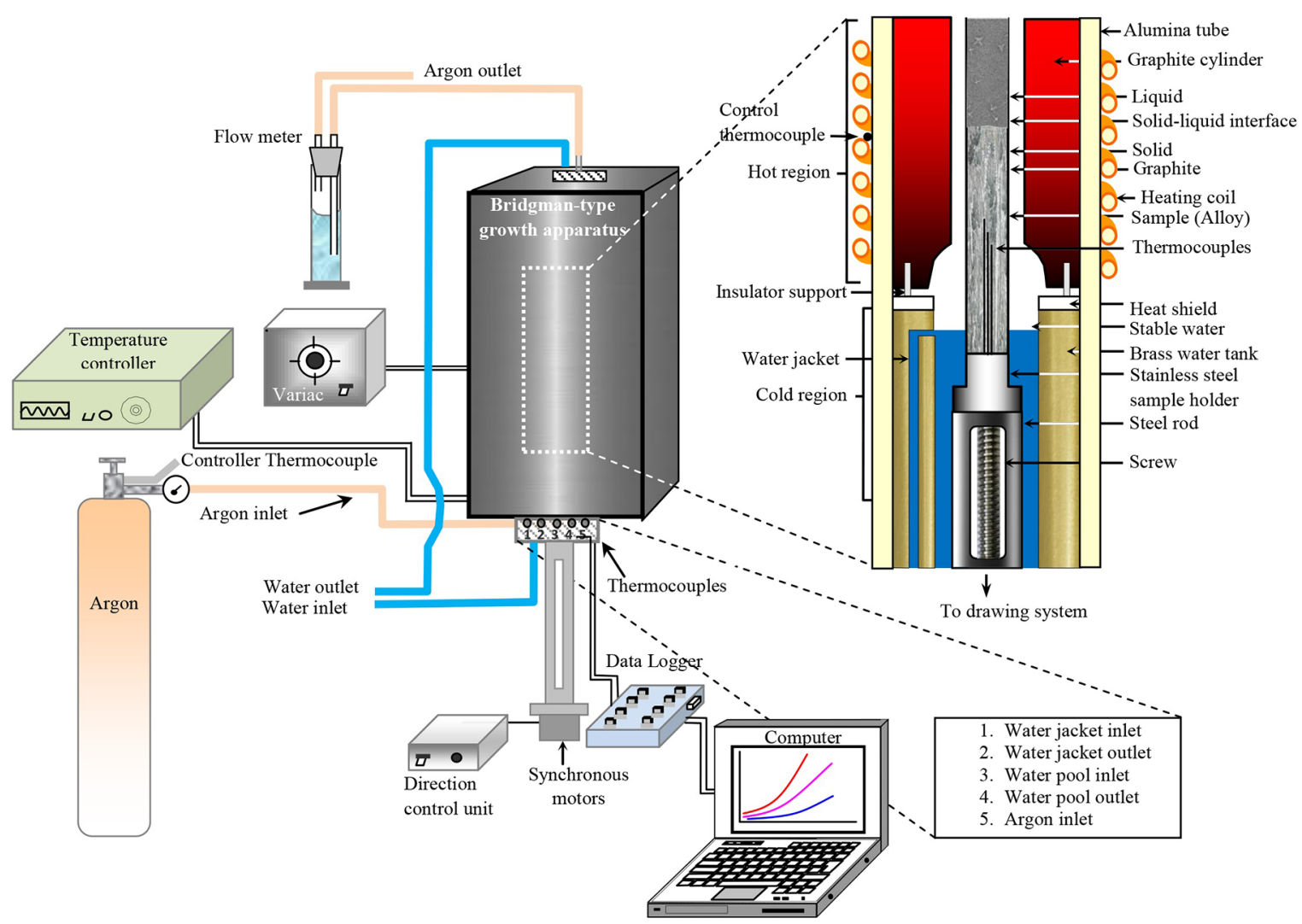

Figure 2. The details of the Bridgman-type growth apparatus. 
in length from the top and bottom. The specimens were then cold mounted with epoxy-resin. The longitudinal and transverse sections were wet ground down to grit 4000 and mechanically polished using $1 \mu \mathrm{m}, 1 / 4 \mu \mathrm{m}$ and $1 / 10 \mu \mathrm{m}$ diamond paste. Finally, the specimens were etched with a Modified Keller's reagent $\left(10 \mathrm{ml} \mathrm{HNO}_{3}, 1.5 \mathrm{ml} \mathrm{HCl}, 1 \mathrm{ml} \mathrm{HF}, 87.5\right.$ $\mathrm{ml}$ distilled water) about $35 \mathrm{~s}$ to reveal the microstructure. After metallographic preparation, the microstructures of the specimens were revealed. The microstructures of specimens were characterized from both transverse and longitudinal sections of specimens using a Nikon (Eclipse MA 100 inverted model) optical microscopy.

\subsection{Measurement of microhardness}

Another purpose of this investigation was to obtain the relationships between solidification parameters ( $V$ and $C o$ ) and microhardness of the studied alloys. Microhardness testing is a speedy and low cost method to characterize mechanical property of materials because it does not require preparing specimens with complex processes. It is widely used as a non-destructive or less destructive method to evaluate the mechanical property and quality control. Microhardness measurements (all specimens were tested according to ASTM E384) in this work were made with a Future-Tech FM-700 model hardness measuring test device ${ }^{30}$ using a $300 \mathrm{~g}$ load and a dwell time of 10 seconds giving a typical indentation depth of about 40-50 $\mu \mathrm{m}$ (see Fig.3). The microhardness values were measured from both longitudinal and transverse sections of samples. The minimum impression spacing (center to edge of adjacent impression) was about 3 times the diagonal and was located at least $0.5 \mathrm{~mm}$ from the edge of the sample. The samples were polished prior to HV measurement to ensure cleanliness of the surfaces. For microhardness measurements, at least ten points for each one of the examined triplicate specimens were tested, and arithmetical mean values were determined. The highest and the lowest values of the ten readings were disregarded.

\section{Result and Discussion}

\subsection{Microstructural evolution}

The experimental results show that the solidification processing parameters strongly effect on the solidification morphology. The effects of similar solidification processing parameters (cooling rates: $0.1-2.5 \mathrm{~K} / \mathrm{s}$ ) can be seen in sand casting and/or permanent steel applications of Al-Zn alloys ${ }^{15-18}$. In this work, cellular and dendritic microstructures were obtained depending on $\mathrm{V}(8.25-165 \mu \mathrm{m} / \mathrm{s})$ at a $\mathrm{G}(10.3 \mathrm{~K} /$ $\mathrm{mm}$ ) (that is cooling rates: $0.09-1.7 \mathrm{~K} / \mathrm{s}$ ). Figures $4-5$ depict the variation of typical dendritic microstructures of Al-Zn alloys in both longitudinal and transverse cross-sections with increasing growth velocity $(V)$ and $\mathrm{Zn}$ concentration $\left(C_{o}\right)$. At a low growth velocity $(8.3 \mu \mathrm{m} / \mathrm{s})$ and a constant
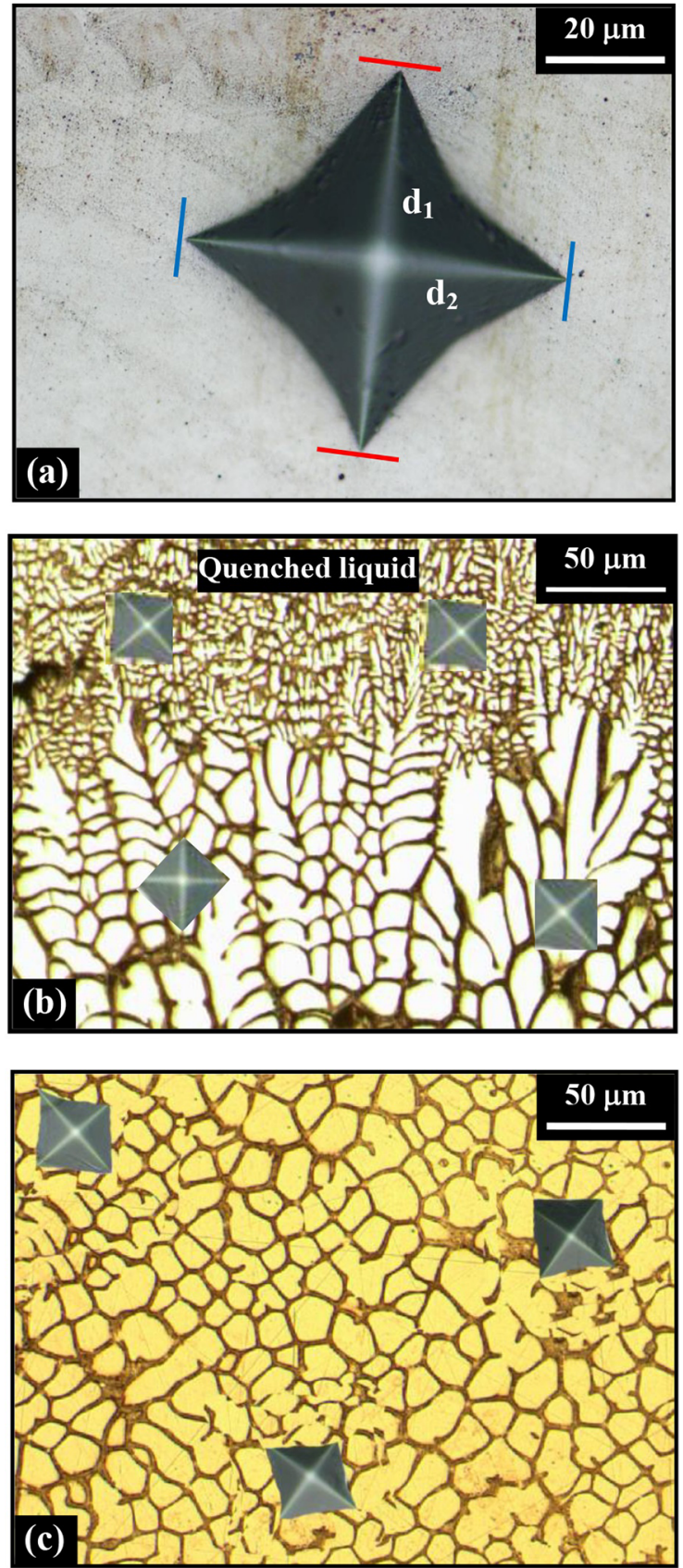

Figure 3. (a) Diagonal lengths $\left(d_{1}\right.$ and $\left.d_{2}\right)$, (b) the indenter traces on the longitudinal microstructure (c) the indenter traces on the transverse microstructure.

temperature gradient $(10.3 \mathrm{~K} / \mathrm{mm})$, a cellular or cellulardendritic microstructure formed. On the other hand, with increasing growth velocity and $\mathrm{Zn}$ content at a constant temperature gradient $(10.3 \mathrm{~K} / \mathrm{mm})$, the transition from a cellular to a dendritic microstructure was completed and the dendritic spacing decreased. The dendritic structure at higher growth velocities $(>41.3 \mu \mathrm{m} / \mathrm{s})$ resembled a peeledcorn shape (see Fig.4 (b3), Fig.5 (a3)). At the high growth velocity $(165 \mu \mathrm{m} / \mathrm{s})$ and high $C_{o}(10-20$ wt pct $\mathrm{Zn})$ at a 


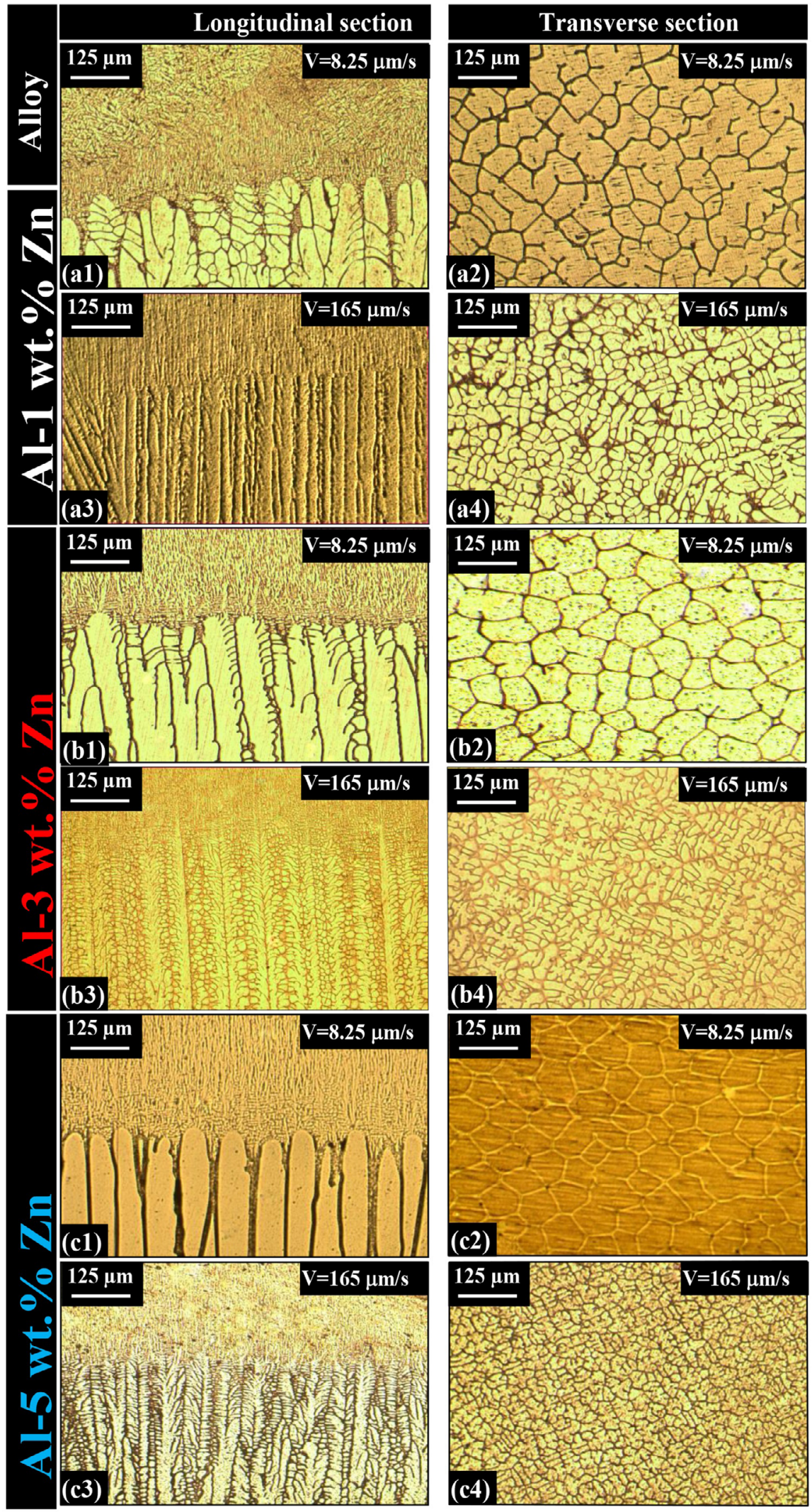

Figure 4. The growth morphologies of the directionally solidified Al- $(1,3,5) \mathrm{wt} . \% \mathrm{Zn}$ alloy for the lowest and the highest growth velocities (a1-a4) Al-1 wt.\% Zn, (b1-b4) Al-3 wt.\% Zn, (c1-c4) Al-5 wt.\% Zn. 


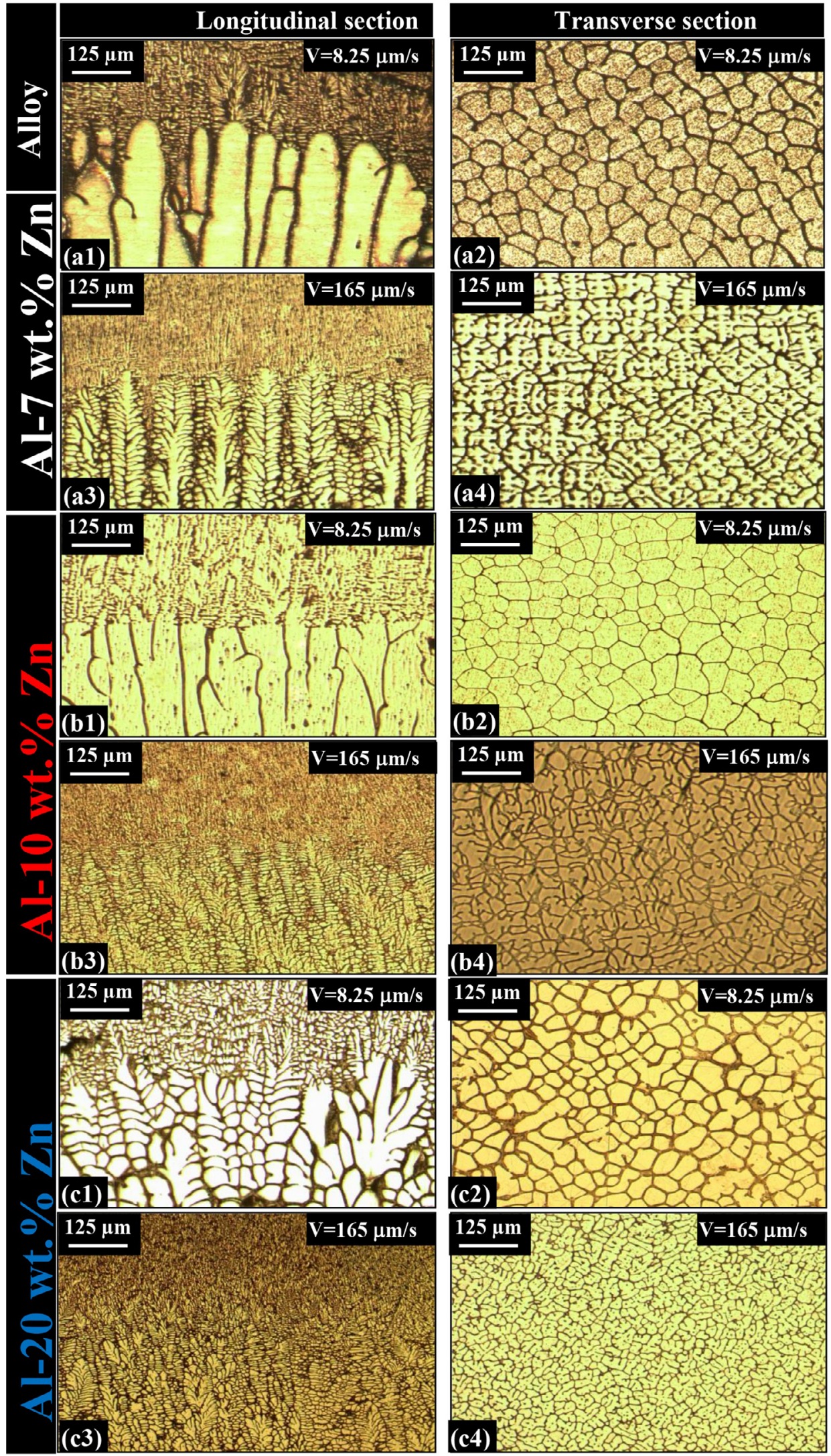

Figure 5. The growth morphologies of the directional solidified Al- $(7,10,20) \mathrm{wt} . \% \mathrm{Zn}$ alloy for the lowest and the highest growth velocities (a1-a4) Al-7 wt.\% Zn, (b1-b4) Al-10 wt.\% Zn, (c1-c4) Al-20 wt.\% Zn. 
constant temperature gradient $(10.3 \mathrm{~K} / \mathrm{mm})$, fine dendrites formed, as shown in Fig. $5\left(\mathrm{~b}_{3}, \mathrm{~b}_{4}\right.$ and $\left.\mathrm{c}_{3}, \mathrm{c}_{4}\right){ }^{29}$.

\subsection{Dependency of the microhardness on the growth velocity}

The variation of the HVL and HVT as a function of the $\mathrm{V}$ is given in Table 1 and Fig. 6a-b. As can be seen from Fig. 6 , the increase in the growth velocity leads to increase in the HVL and HVT for a given constant temperature gradient and $\mathrm{Zn}$ content. It is found that by increasing the $\mathrm{V}$ from 8.25 $\mu \mathrm{m} / \mathrm{s}$ to $165 \mu \mathrm{m} / \mathrm{s}$, microhardness values increased to 283 $\mathrm{MPa}(37 \%$ increase), $301 \mathrm{MPa}$ (32\% increase), $342 \mathrm{MPa}$ (25\% increase), $495 \mathrm{MPa}$ ( $34 \%$ increase), $726 \mathrm{MPa}(18 \%$ increase) and $984 \mathrm{MPa}(17 \%$ increase $)$ for $\mathrm{Al}-\mathrm{xZn}(\mathrm{x}=1,3$, 5, 7, 10 and 20 wt. \%) alloys, respectively. The dependence of the microhardness $\mathrm{HV}$ on the $V$ was determined by using linear regression analysis, and the relationship between them can be expressed as

$$
H V=k_{i} V^{m}
$$

where $\mathrm{m}$ is the exponent value of the growth velocity, $\mathrm{k}_{\mathrm{i}}$ is a constant which can be experimentally determined and given in Table 1. The values of the exponent relating to the growth velocity were obtained to be $(0.10,0.10),(010,0.09)$, $(0.08,0.06),(0.09,0.08),(0.06,0.05)$ and $(0.05,0.06)$ for the longitudinal and transverse sections of $\mathrm{Al}-\mathrm{xZn}(\mathrm{x}=1,3$, $5,7,10$ and $20 \mathrm{wt}$ \%) alloys, respectively. The experiment constant values $\mathrm{k}_{\mathrm{i}}$ increase about 5 times for the compositions change from $\mathrm{Al}-1 \mathrm{wt} . \% \mathrm{Zn}$ to Al-20 wt.\% $\mathrm{Zn}$ and correlation coefficients are between 0.917-0.995.

These exponent values relating to the growth rates have been compared with the exponent values relating to the growth rates obtained in previous works ${ }^{(32-35,42-47)}$ for the
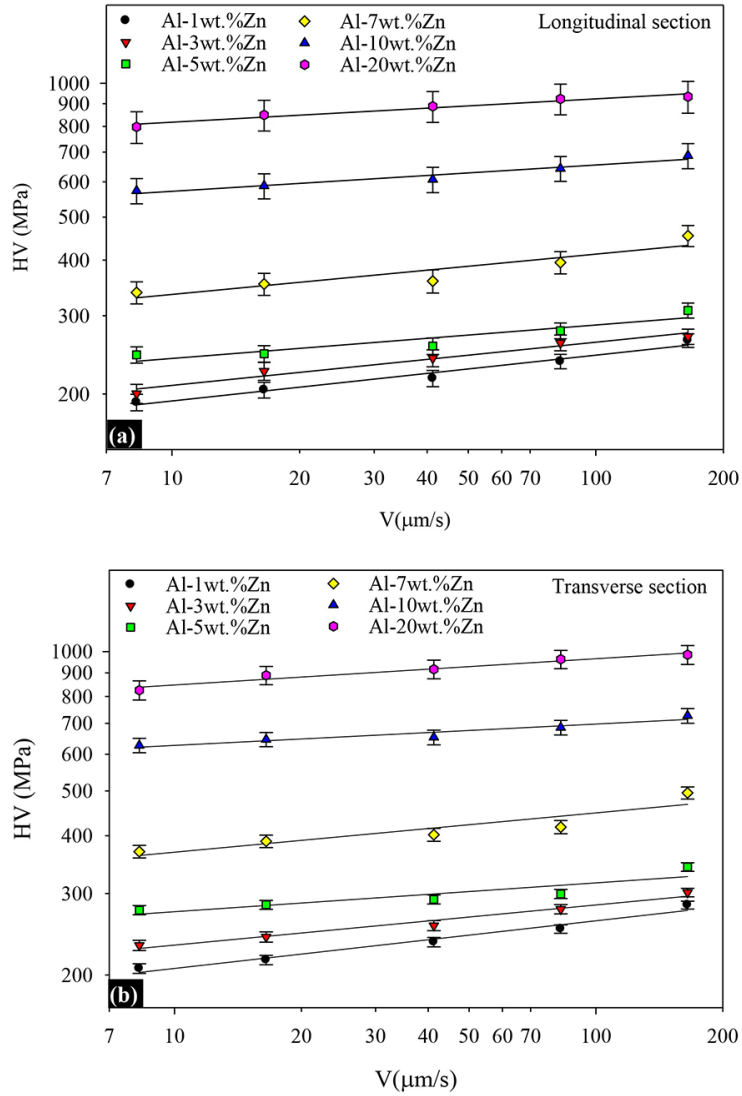

Figure 6. The variation of microhardness with growth velocity for different Al-Zn compositions (a) Longitudinal section (b) Transverse section.

similar solidification conditions in different alloy systems. The values of the exponent $\mathrm{m}$ obtained in this study are in good agreement with the values of $0.11,0.10,0.09,0.12,0.08$, $0.10,0.09,0.14$ and 0.24 obtained by Kaya et al. ${ }^{32}$ for $\mathrm{Pb}-\mathrm{Cd}$, $\mathrm{Sn}-\mathrm{Zn}, \mathrm{Bi}-\mathrm{Cd}$, by Kaya et al. ${ }^{33}$ for Al-Si, Khan et al. ${ }^{34}$ for Al$\mathrm{Si}$, Telli and Kisakurek ${ }^{35}$ for Al-Si, Vnuk et al. ${ }^{42}$ for $\mathrm{Sn}-\mathrm{Zn}$,

Table 1. The relationships between microhardness and growth velocity for different $\mathrm{Zn}$ content

\begin{tabular}{llll}
\hline Composition (wt.\%) & \multicolumn{1}{c}{ Relationships } & Constant $(\mathrm{k})$ & Correlation coefficient (r) \\
\hline \multirow{2}{*}{ Al-1 Zn } & $H V_{L}=\mathrm{k}_{1} V^{0.10}$ & $\mathrm{k}_{1}=152 \mathrm{MPa} \mu \mathrm{m}^{0.10} \mathrm{~s}^{-0.10}$ & $\mathrm{r}_{1}=0.985$ \\
& $H V_{T}=\mathrm{k}_{2} V^{0.10}$ & $\mathrm{k}_{2}=163 \mathrm{MPa} \mu \mathrm{m}^{0.10} \mathrm{~s}^{-0.10}$ & $\mathrm{r}_{2}=0.985$ \\
& $H V_{L}=\mathrm{k}_{3} V^{0.10}$ & $\mathrm{k}_{3}=167 \mathrm{MPa} \mu \mathrm{m}^{0.10} \mathrm{~s}^{-0.10}$ & $\mathrm{r}_{3}=0.983$ \\
Al-3 Zn & $H V_{T}=\mathrm{k}_{4} V^{0.09}$ & $\mathrm{k}_{4}=190 \mathrm{MPa} \mu \mathrm{m}^{0.09} \mathrm{~s}^{-0.09}$ & $\mathrm{r}_{4}=0.985$ \\
& $H V_{L}=\mathrm{k}_{5} V^{0.08}$ & $\mathrm{k}_{5}=202 \mathrm{MPa} \mu \mathrm{m}^{0.08} \mathrm{~s}^{-0.08}$ & $\mathrm{r}_{5}=0.934$ \\
Al-5 Zn & $H V_{T}=\mathrm{k}_{6} V^{0.06}$ & $\mathrm{k}_{6}=237 \mathrm{MPa} \mu \mathrm{m}^{0.09} \mathrm{~s}^{-0.09}$ & $\mathrm{r}_{6}=0.899$ \\
& $H V_{L}=\mathrm{k}_{7} V^{0.09}$ & $\mathrm{k}_{7}=271 \mathrm{MPa} \mu \mathrm{m}^{0.09} \mathrm{~s}^{-0.09}$ & $\mathrm{r}_{7}=0.930$ \\
Al-7 Zn & $H V_{T}=\mathrm{k}_{8} V^{0.08}$ & $\mathrm{k}_{8}=308 \mathrm{MPa} \mu \mathrm{m}^{0.08} \mathrm{~s}^{-0.08}$ & $\mathrm{r}_{8}=0.917$ \\
& $H V_{L}=\mathrm{k}_{9} V^{0.06}$ & $\mathrm{k}_{9}=498 \mathrm{MPa} \mu \mathrm{m}^{0.06} \mathrm{~s}^{-0.06}$ & $\mathrm{r}_{9}=0.974$ \\
Al-10 Zn & $H V_{T}=\mathrm{k}_{10} V^{0.05}$ & $\mathrm{k}_{10}=564 \mathrm{MPa} \mu \mathrm{m}^{0.05} \mathrm{~s}^{-0.05}$ & $\mathrm{r}_{10}=0.956$ \\
& $H V_{L}=\mathrm{k}_{11} V^{0.05}$ & $\mathrm{k}_{11}=724 \mathrm{MPa} \mu \mathrm{m}^{0.05} \mathrm{~s}^{-0.05}$ & $\mathrm{r}_{11}=0.979$ \\
Al-20 Zn & $H V_{T}=\mathrm{k}_{12} V^{0.06}$ & $\mathrm{k}_{12}=743 \mathrm{MPa} \mu \mathrm{m}^{0.06} \mathrm{~s}^{-0.06}$ & $\mathrm{r}_{12}=0.980$ \\
& & &
\end{tabular}

$\mathbf{H V}_{\mathbf{L}}$ : the values of the microhardness measured from the longitudinal section near to the $\mathrm{S} / \mathrm{L}$ interface in the solid phase of the specimens $\mathbf{H V}_{\mathbf{T}}$ : the values of the microhardness measured from the transverse section near to the $\mathrm{S} / \mathrm{L}$ interface in the solid phase of the specimens 
respectively. Our exponent values are smaller than the values of 0.14 and 0.24 obtained by Lapin et al. ${ }^{43}$ for Ti-Al-W-Si, and Ma et al. ${ }^{44}$ for $\mathrm{Zn}-\mathrm{Cu}$ for different alloys, Also, our exponent values are greater than the values of $0.040,0.034$ and 0.023 obtained by Y1lmaz and Elliot ${ }^{45}$ and Y1lmaz ${ }^{46}$ and Perdrix et al. ${ }^{47}$ for different alloy systems, respectively. Differences exist in the values because of the possible differences in solidification conditions, microstructures, the compositions of the samples and their purity. As can be seen in Fig. 8, the quenched liquid phase has a higher microhardness than the solid phase because liquid phase has smaller microstructures than the directionally solidified phase.

\subsection{Dependency of the microhardness on the $\mathrm{Zn}$ content}

Variations of the values of $\mathrm{HV}$ as a function of $\mathrm{Zn}$ content at a constant temperature gradient and given growth velocities are given in Table 2 and Fig. 7a-b for longitudinal and transverse secions. HV values increase with the increasing $\mathrm{Zn}$ content. Also, it is found that by increasing the $\mathrm{Zn}$ content from $1 \mathrm{wt}$. $\% \mathrm{Zn}$ to $20 \mathrm{wt}$.\% Zn, microhardness values increased to 825 $\mathrm{MPa}(408 \%$ increase), $888 \mathrm{MPa}(414 \%$ increase), $915 \mathrm{MPa}$ (400\% increase), $962 \mathrm{MPa}(387 \%$ increase) and $984 \mathrm{MPa}$ (350\% increase) for growth velocities $(8.25,16.5,41.25,82.5$ and $165 \mu \mathrm{m} / \mathrm{s})$ at a constant $\mathrm{G}(10.3 \mathrm{~K} / \mathrm{mm})$, respectively.

Shin et al. ${ }^{48}$ were investigated the microhardness of Al-Zn alloys using die-casting method and found that microhardness increased with increased $\mathrm{Zn}$ content. As the amount of $\mathrm{Zn}$ was increased, the fraction of grain boundary regions in the developed Al-Zn based alloys also significantly increased, changing the mechanical properties of the alloys as a result. The HV value ( $800 \mathrm{MPa}$ ) obtained by us for the Al-20 Zn alloy is very close to the $\mathrm{HV}$ value $(770 \mathrm{MPa})$ obtained by these researchers for the same composition alloy. In addition, Mazilkin et al. ${ }^{49}$ measured microhardness values for Al-(10, 20 and $30 \mathrm{wt}$. \%) Zn alloys, and they found a similar tendency to our findings. According to these researchers, the increase in microhardness with increasing $\mathrm{Zn}$ content in the studied
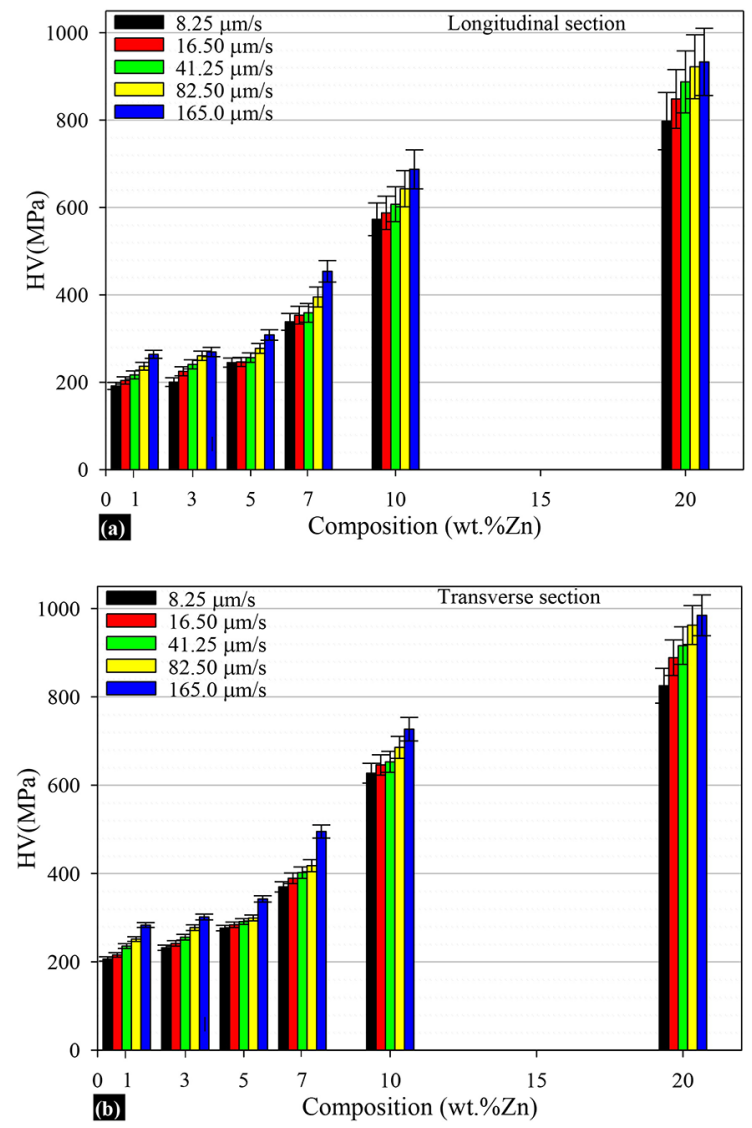

Figure 7. The variation of microhardness with composition for solid phase obtained with different growth velocities (a) Longitudinal section (b) Transverse section.

alloys was owing to the solid solution strengthening. They reported microhardness values of 830,930 and $950 \mathrm{MPa}$ for Al-10Zn, Al-20Zn and Al-30Zn alloys, respectively. These values are in quite good agreement with our microhardness results. Recently, in a study conducted by Chinh et al. ${ }^{50} \mathrm{Al}-(2$, 5 and $10 \mathrm{wt} . \%$ ) Zn alloys were processed by high-pressure torsion (HPT) to produce ultrafine-grained (UFG) materials.

Table 2. The relationships between microhardness and composition for different growth velocity.

\begin{tabular}{llll}
\hline Growth velocity $(\mu \mathrm{m} / \mathrm{s})$ & \multicolumn{1}{c}{ Relationships } & \multicolumn{1}{c}{ Constant $(\mathrm{k})$} & \multicolumn{1}{c}{ Correlation coefficient (r) } \\
\hline \multirow{2}{*}{8.25} & $H V_{L}=\mathrm{k}_{13} C_{0}^{0.51}$ & $\mathrm{k}_{13}=144 \mathrm{MPa}(\mathrm{wt} . \%)^{-0.51}$ & $\mathrm{r}_{13}=0.903$ \\
& $H V_{T}=\mathrm{k}_{14} C_{0}^{0.50}$ & $\mathrm{k}_{14}=162 \mathrm{MPa}(\mathrm{wt} . \%)^{-0.50}$ & $\mathrm{r}_{14}=0.917$ \\
& $H V_{L}=\mathrm{k}_{15} C_{0}^{0.50}$ & $\mathrm{k}_{15}=155 \mathrm{MPa}(\mathrm{wt} . \%)^{-0.50}$ & $\mathrm{r}_{15}=0.898$ \\
& $H V_{T}=\mathrm{k}_{16} C_{0}^{0.50}$ & $\mathrm{k}_{16}=168 \mathrm{MPa}(\mathrm{wt} . \%)^{-0.50}$ & $\mathrm{r}_{16}=0.0 .916$ \\
& $H V_{L}=\mathrm{k}_{17} C_{0}^{0.50}$ & $\mathrm{k}_{17}=164 \mathrm{MPa}(\mathrm{wt} . \%)^{-0.50}$ & $\mathrm{r}_{17}=0.892$ \\
& $H V_{T}=\mathrm{k}_{18} C_{0}^{0.48}$ & $\mathrm{k}_{18}=181 \mathrm{MPa}(\mathrm{wt} \%)^{-0.48}$ & $\mathrm{r}_{18}=0.904$ \\
& $H V_{L}=\mathrm{k}_{19} C_{0}^{0.48}$ & $\mathrm{k}_{19}=181 \mathrm{MPa}(\mathrm{wt} . \%)^{-0.48}$ & $\mathrm{r}_{19}=0.894$ \\
& $H V_{T}=\mathrm{k}_{20} C_{0}^{0.47}$ & $\mathrm{k}_{20}=194 \mathrm{MPa}(\mathrm{wt} . \%)^{-0.47}$ & $\mathrm{r}_{20}=0.0896$ \\
& $H V_{L}=\mathrm{k}_{21} C_{0}^{0.46}$ & $\mathrm{k}_{21}=202 \mathrm{MPa}(\mathrm{wt} . \%)^{-0.46}$ & $\mathrm{r}_{21}=0.894$ \\
& $H V_{T}=\mathrm{k}_{22} C_{0}^{0.45}$ & $\mathrm{k}_{22}=222 \mathrm{MPa}(\mathrm{wt} . \%)^{-0.45}$ & $\mathrm{r}_{22}=0.908$ \\
\hline
\end{tabular}

$\mathbf{H V}_{\mathbf{L}}$ : the values of the microhardness measured from the longitudinal section near to the $\mathrm{S} / \mathrm{L}$ interface in the solid phase of the specimens $\mathbf{H V}_{\mathrm{T}}$ : the values of the microhardness measured from the transverse section near to the $\mathrm{S} / \mathrm{L}$ interface in the solid phase of the specimens 


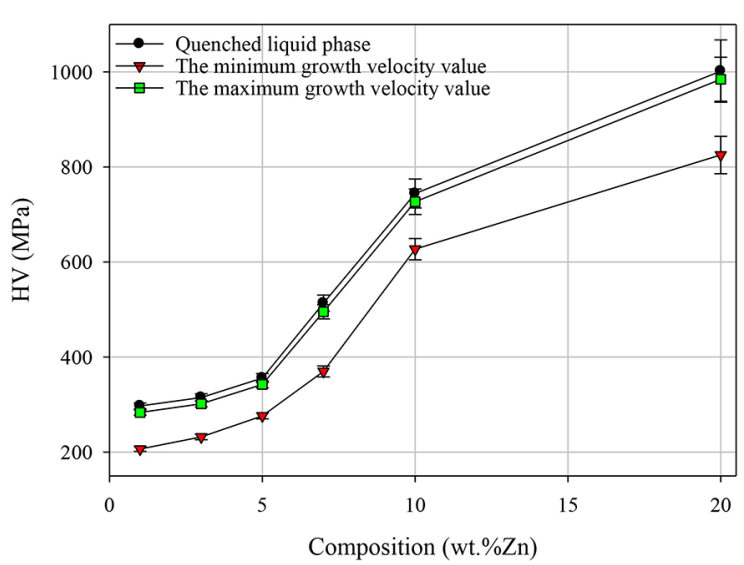

Figure 8. The variation of measured microhardness with composition for quenched liquid and solid phases obtained with the maximum and minimum growth velocities.

These researchers found that the microhardness increased from 450 to $730 \mathrm{MPa}$ with the increase of $\mathrm{Zn}$ content.

The dependence of $\mathrm{HV}$ on $\mathrm{C}_{\mathrm{o}}$ can be represented as

$$
H V=k_{i} C_{o}^{n}
$$

where $\mathrm{n}$ is the exponent value of the $\mathrm{Zn}$ content, $\mathrm{k}_{\mathrm{i}}$ is a constant which can be experimentally determined and given in Table 2. The values of the exponent relating to the $\mathrm{Zn}$ content were obtained to be $(0.51,0.50),(0.50,0.50),(0.50$, $0.48),(0.48,0.47)$ and $(0.46,0.45)$ for the longitudinal and transverse sections of Al-xZn ( $\mathrm{x}=1,3,5,7,10$ and $20 \mathrm{wt}$. \%) alloys, respectively. As can be seen from the exponent values in the obtained relationships, the effect of $\mathrm{Zn}$ content at a constant $\mathrm{G}$ and given $\mathrm{V}$ is more effective on the microhardness of the studied alloys than the growth velocity at a constant $\mathrm{G}$ and $\mathrm{Zn}$ content. Experimental $\mathrm{k}_{\mathrm{i}}$ values change from 144 to $222 \mathrm{MPa}$ (wt.\%).

The average exponent values $(0.45-0.51)$ of the $\mathrm{Co}$ is in good agreement with the exponent values of $0.51,0.42,0.53$ and 0.49 found by Al-Rawajfeh et al. ${ }^{51}$ for pure $\mathrm{Al}$ and $\mathrm{Al}-\mathrm{Cu}$ alloy, Mazilkin et al. ${ }^{49}$ for Al-Zn and Al-Mg alloys, Chinh et al. ${ }^{50}$ for Al-Zn alloy and Igelegbai et al. ${ }^{52}$ for $\alpha$-brass alloys, respectively. However, average exponent values of Co are smaller than the values of 0.86 and 0.74 reported by Lamrous et al. ${ }^{36}$ and Shin et al. ${ }^{48}$ for Al-Zn alloys, respectively. Differences in the exponent values might be owing to the differences in elements, purity, alloy compositions, solidification conditions and surface preparation of the test pieces. As expected, the growth rate increases while the cooling rate $(T=G V)$ of the alloys increases for the constant $\mathrm{G}$. Therefore, the regions that are most exposed to cooling are quenched liquid regions. Figure 8 shows the microhardness values obtained for minimum growth velocity, maximum growth velocity and quench process with increasing $\mathrm{Zn}$ content. As seen from this figure, while the $\mathrm{Zn}$ contents increased from 1 to 20 wt. $\%$, the microhardness values increased from $300 \mathrm{MPa}$ to
$1000 \mathrm{MPa}$ for the quenched liquid region. Some errors are inevitable during microhardness measurements. These errors are due to factors such as surface quality, inhomogeneities in the microstructure and ambiguity of indenter traces. The estimated error in the microhardness measurements with statistical data analysis is about $5 \%$.

\section{Conclusions}

In the present work, $\mathrm{Al}-\mathrm{xZn}(\mathrm{x}=1,3,5,7,10$ and $20 \mathrm{wt}$. $\%)$ alloys were directionally solidified at constant $\mathrm{G}$ (10.3 $\mathrm{K} / \mathrm{mm})$ with different $\mathrm{V}(8.3-165 \mu \mathrm{m} / \mathrm{s})$. The microstructural changes of the solidified specimens were observed. Effects of the growth velocity and $\mathrm{Zn}$ content on the microhardness of the studied alloys were examined. The following conclusions were reached:

1. The cellular microstructure formed at low growth velocities $(<16.5 \mu \mathrm{m} / \mathrm{s})$. The cell/dendrite transition has been observed at growth velocities less than 16.5 $\mu \mathrm{m} / \mathrm{s}$. With the increasing of the growth velocity in the range of $8.25-165 \mu \mathrm{m} / \mathrm{s}$, the microstructures of the solidified alloys are found to evolve firstly from the cellular or cellular/dendritic to refined dendrites and eventually to fine dendritic morphology at high growth velocity $(165 \mu \mathrm{m} / \mathrm{s})$.

2. By increasing $\mathrm{V}, \mathrm{HV}$ increased. It is found that $\mathrm{HV}$ increases from 206, 231, 276, 369, 627 and 825 $\mathrm{MPa}$ to 283, 301, 342, 495, 726 and $984 \mathrm{MPa}$ for each $\mathrm{Zn}$ content, respectively. The establishment of the relationships between $\mathrm{HV}$ and $\mathrm{V}$ can be given as $\mathrm{HV}=\mathrm{kV}^{\mathrm{m}}(\mathrm{m}=0.05-0.10)$.

3. Also, by increasing $\mathrm{Zn}$ content, HV increased. It is found that HV increases from 206, 215, 235, 251 and $283 \mathrm{MPa}$ to $825,888,915,962$ and 984 $\mathrm{MPa}$ for each growth velocity, respectively. The establishment of the relationships between $\mathrm{HV}$ and $\mathrm{C}_{\mathrm{o}}$ can be given as $\mathrm{HV}=\mathrm{kC}_{\mathrm{o}}{ }^{\mathrm{n}}(\mathrm{n}=0.45-0.51)$. Thus, characteristics of $\mathrm{V}$ and $\mathrm{C}_{\mathrm{o}}$ play a vital role for a good combination of microstructure and microhardness.

\section{Acknowledgments}

This project was supported by the Erciyes University Scientific Research Project Unit under Contract No: FDK2013-4756. The authors are grateful for this financial support.

\section{References}

1. Goulart PR, Cruz KS, Spinelli JE, Ferreira IL, Cheung N, Garcia A. Cellular growth during transient directional solidification of hypoeutectic Al-Fe alloys. Journal of Alloy and Compounds. 2009;470(-2):589-599. 
2. Průša F, Vojtěch D, Michalcová A, Marek I. Mechanical properties and thermal stability of Al-Fe-Ni alloys prepared by centrifugal atomisation and hot extrusion. Materials Science and Engineering: A. 2014;603:141-149.

3. Sauthoff G. Multiphase intermetallic alloys for structural applications. Intermetallics. 2000;8(9-11):1101-1109.

4. Löffler H, ed. Structure and Structure Development of Al-Zn Alloys. Berlin: Akademie Verlag; 1995.

5. Lamrous D, Debili MY, Boehm-Courjault E. Microstructure and Phase Composition of Al-Zn alloys. Journal of Advanced Microscopy Research. 2013;8(4):266-269.

6. Hilliard JE, Averbach BL, Cohen M. Thermodynamic properties of solid aluminum-zinc alloys. Acta Metallurgica. 1954;2(4):621631.

7. Hansen M, ed. Constitution of Binary Alloys. New York: McGraw-Hill; 1958.

8. Gonzales F, Rappaz M. Dendrite growth directions in aluminumzinc alloys. Metallurgical and Materials Transactions $A$. 2006;37(9):2797-2806.

9. Rhême M, Gonzales F, Rappaz M. Growth directions in directionally solidified $\mathrm{Al}-\mathrm{Zn}$ and $\mathrm{Zn}-\mathrm{Al}$ alloys near eutectic composition. Scripta Materialia. 2008;59(4):440-443.

10. Osamura K, Okuda $\mathrm{H}$, Ochiai S. Isothermal phase decomposition diagram in Al-Zn binary alloys. Scripta Materialia. 1985;19(11):1379-1384.

11. Osório WR, Spinelli JE, Cheung N, Garcia A. Secondary dendrite arm spacing and solute redistribution effects on the corrosion resistance of Al $-10 \mathrm{wt} \% \mathrm{Sn}$ and $\mathrm{Al}-20 \mathrm{wt} \% \mathrm{Zn}$ alloys. Materials Science and Engineering: A. 2006;420(1-2):179-186.

12. Zhu YH. General Rule of Phase Decomposition in Zn-Al Based Alloys (II) - on Effects of External Stresses on Phase Transformation. Materials Transactions. 2004;45(11):30833097.

13. Demirtas M, Purcek G, Yanar H, Zhang ZJ, Zhang ZF. Effect of Chemical Composition and Grain Size on RT Superplasticity of $\mathrm{Zn}-\mathrm{Al}$ Alloys Processed by ECAP. Letters on Materials. 2015;5(3):328-334.

14. Skoko Ž, Popović S, Štefanić G. Microstructure of Al-Zn and Zn-Al Alloys. Croatica Chemica Acta. 2009;82(2):405-420.

15. Maube SE, Wangombe DN, Maranga SM, Kihiu JM. Effect of Cooling Rate and Heat Treatment on the Microstructure and Impact Resistance of Recycled Aluminium Sand Cast Alloy. Journal of Sustainable Research in Engineering. 2014;1(1):2430 .

16. Mehr FH, Reilly C, Cockcroft S, Maijer D, Mackay R. Effect of chill cooling conditions on cooling rate, microstructure and casting/chill interfacial heat transfer coefficient for sand cast A319 alloy. International Journal of Cast Metals Research. 2014;27(5):288-300.

17. Kurz W, Fisher DJ. Fundamentals of Solidification. $3^{\text {rd }}$ ed. Aedermannsdorf: Trans Tech Publications; 1989.

18. Akhil KT, Arul S, Sellamuthu R. The Effect of Section Size on Cooling Rate, Microstructure and Mechanical Properties of A356 Aluminium Alloy in casting. Procedia Materials Science. 2014;5:362-368.
19. Bayram Ü, Karamazi Y, Ata P, Aksöz S, Keslioglu K, Marasli N. Dependence of microstructure microhardness, tensile strength and electrical resistivity on growth rates for directionally solidified Zn-Al-Sb eutectic alloy. International Journal of Materials Research. 2016;107(11):1005-1015.

20. Bayram Ü, Marasli N. Thermal conductivity and electrical resistivity dependences on growth rate in the directionally solidified Al-Cu-Ni eutectic alloy. Journal of Alloys and Compounds. 2018;753:695-702.

21. Cruz CB, Kakitani R, Xavier MGC, Silva BL, Garcia A, Cheung N, et al. Transient Unidirectional Solidification, Microstructure and Intermetallics in Sn-Ni Alloys. Materials Research. 2018;21(Suppl 1):e20171099.

22. Xu W, Feng YP, Li Y, Li ZY. Cellular growth of Zn-rich Zn-Ag alloys processed by rapid solidification. Materials Science and Engineering: A. 2004;373(1-2):139-145.

23. Sá F, Rocha OL, Siqueira CA, Garcia A. The effect of solidification variables on tertiary dendrite arm spacing in unsteady-state directional solidification of $\mathrm{Sn}-\mathrm{Pb}$ and $\mathrm{Al}-\mathrm{Cu}$ alloys. Materials Science and Engineering A. 2004;373:131-138.

24. Liu YC, Han Y, Yang GC, Zhou YH. Primary cellular/dendritic spacing selection in rapidly solidified peritectic alloy. Materials Letters. 2005;59(23):2915-2919.

25. Rosa DM, Spinelli JE, Garcia A. Tertiary dendrite arm spacing during downward transient solidification of $\mathrm{Al}-\mathrm{Cu}$ and $\mathrm{Al}-\mathrm{Si}$ alloys. Materials Letters. 2006;60(15):1871-1874.

26. Burden MH, Hebditch DJ, Hunt JD. Macroscopic stability of a planar, cellular or dendritic interface during directional freezing. Journal of Crystal Growth. 1973;20(2):121-124.

27. Jones H. Rapid Solidification of Metals and Alloys. London: Institution of Metallurgists; 1982.

28. Gündüz M, Çadırlı E. Directional solidification of aluminiumcopper alloys. Materials Science and Engineering: A. 2002;327(2):167-185

29. Acer E, Çadırlı E, Erol H, Kaya H, Gündüz M. Effects of Growth Rates and Compositions on Dendrite Arm Spacings in Directionally Solidified Al-Zn Alloys. Metallurgical and Materials Transactions A. 2017;48(12):5911-5923.

30. Çadırlı E, Kaya H, Sahin M. Effects of Cooling Rate and Composition on Mechanical Properties of Directionally Solidified $\mathrm{Pb}(100-\mathrm{x})-\mathrm{Snx}$ Solders. Journal of Electronic Materials. 2011;40(9):1903-1911.

31. Çadırlı E, Aker A, Kaygısız Y, Şahin M. Influences of Growth Velocity and Fe Content on Microstructure, Microhardness and Tensile Properties of Directionally Solidified Al-1.9Mn-xFe Ternary Alloys. Materials Research. 2017;20(3):801-813.

32. Kaya H, Gündüz M, Çadırlı E, Uzun O. Effect of growth rate and lamellar spacing on microhardness in the directionally solidified Pb-Cd, Sn-Zn and Bi-Cd eutectic alloys. Journal of Material Science. 2004;39(21):6571-6576.

33. Kaya H, Çadırlı E, Gündüz M, Ülgen A. Effect of the temperature gradient, growth rate, and the interflake spacing on the microhardness in the directionally solidified Al-Si eutectic alloy. Journal of Materials Engineering and Performance. 2003;12(5):544-551. 
34. Khan S, Ourdjini A, Hamed QS, Najafabadi MAA, Elliott R. Hardness and mechanical property relationships in directionally solidified aluminium-silicon eutectic alloys with different silicon morphologies. Journal of Materials Science. 1993;28(21):5957-5962.

35. Telli AI, Kısakürek SE. Effect of antimony additions on hardness and tensile properties of directionally solidified Al-Si eutectic alloy. Journal of Materials Science and Technology. 1988;4(2):153-156.

36. Lamrous D, Boehm-Courjault E, Debili MY, Sassane N. Effect of impurities on microstructure of the as-cast and heat treated Al-Zn alloys. Metallurgical and Materials Engineering - Association of Metallurgical Engineers of Serbia. 2014;20(1):23-34.

37. Donelan P. Modelling microstructural and mechanical properties of ferritic ductile cast iron. Materials Science and Technology. 2000;16(3):261-269.

38. Osório WR, Siqueira CA, Freire CMA, Garcia A. Effects of the longitudinal and transversal structural grain morphologies upon the corrosion resistance of zinc and aluminium specimens. Revista de Metalurgia. 2005;41(Spec Vol):176-180.

39. Rosa DM, Spinelli JE, Osório WR, Garcia A. Effects of cell size and macrosegregation on the corrosion behavior of a dilute Pb-Sb alloy. Journal of Power Sources. 2006;162(1):696-705.

40. Iecks G, Maiolo LMA, Bortolozo AD, Osório WR. Designing a Microstructural Array Associated with Hardness of Dualphase $\mathrm{Cu}-\mathrm{Zn}$ Alloy Using Investment Casting. Materials Research. 2018;21(4):e20171059.

41. Bonatti RS, Siqueira RR, Padilha GS, Bortolozo AD, Osório WR. Distinct Alp/Sip composites affecting its densification and mechanical behavior. Journal of Alloys and Compounds. 2018;757:434-447.

42. Vnuk F, Sahoo M, Baragar D, Smith RW. Mechanical properties of the Sn-Zn eutectic alloys. Journal of Materials Science. 1980;15(10):2573-2583.
43. Lapin J, Ondrúš L', Nazmy M. Directional solidification of intermetallic Ti-46Al-2W-0.5Si alloy in alumina moulds. Intermetallics. 2002;10(10):1019-1031.

44. Ma D, Li Y, Wang FD, Li ZY. Laser resolidification of a Zn-3.37 wt $\% \mathrm{Cu}$ peritectic alloy. Materials Science and Engineering: A. 2001;318(1-2):235-243.

45. Yilmaz F, Elliott R. The microstructure and mechanical properties of unidirectionally solidified Al-Si alloys. Journal of Materials Science. 1989;24:2065-2070.

46. Yilmaz F. Structure and properties of directionally solidified Al-Si hypereutectic alloys. Materials Science and Engineering. A. 1990;124(2):L1-L5.

47. Perdrix F, Trichet MF, Bonnentien JL, Cornet M, Bigot J. Influence of cooling rate on microstructure and mechanical properties of a Ti-48Al alloy. Intermetallics. 1999;7(12):13231328.

48. Shin SS, Lim KM, Park IM. Characteristics and microstructure of newly designed Al-Zn-based alloys for the die-casting process. Journal of Alloys and Compounds. 2016;671:517-526.

49. Mazilkin AA, Straumal BB, Rabkin E, Baretzky B, Enders S, Protasova SG, et al. Softening of nanostructured Al-Zn and Al-Mg alloys after severe plastic deformation. Acta Materialia. 2006;54(15):3933-3939.

50. Chinh NQ, Jenei P, Gubicza J, Bobruk EV, Valiev RZ, Langdon TG. Influence of $\mathrm{Zn}$ content on the microstructure and mechanical performance of ultrafine-grained Al-Zn alloys processed by high-pressure torsion. Materials Letters. 2017;186:334-337.

51. Al-Rawajfeh E, Al-Qawabah SMA. Investigation of copper addition on the mechanical properties and corrosion resistance of commercially pure aluminium. Emirates Journal for Engineering Research. 2009;14(1):47-52.

52. Igelegbai EE, Alo OA, Adeodu AO, Daniyan IA. Evaluation of Mechanical and Microstructural Properties of a-Brass Alloy Produced from Scrap Copper and Zinc Metal through Sand Casting Process. Journal of Minerals and Materials Characterization and Engineering. 2017;5(1):18-28. 